\title{
EXPERIENCE IN THE DEVELOPMENT AND USE OF ALUMINUM ALLOY CASING FOR CONDITIONS OF HIGH CONTENT OF ACID GASES IN FORMATION FLUIDS
}

\author{
Vladimir Sledkov ${ }^{1}$, Mikhail Gelfgat ${ }^{1}$, and Dmitry Basovich ${ }^{2}$ \\ ${ }^{1}$ Gubkin Russian State University of Oil and Gas (National Research University), 65 Leninsky Prospekt, Moscow 119991, Russia \\ ${ }^{2}$ OOO “Aquatic-BT”, 4/10, Stepana Supruna, Moscow 125167 Russia
}

\begin{abstract}
When selecting a casing material for fields with a high content of $\mathrm{H}_{2} \mathrm{~S}$ and $\mathrm{CO}_{2}$, it is recommended to use specialized corrosion-resistant tubulars with high content of chrome of the Sanicro 29 type. The high cost of the material can be critical for the project economy. A promising approach for these problems elimination could be the application of aluminium alloy casing pipes. They are remain inert to corrosion even if the formation environment is fully saturated with $\mathrm{H}_{2} \mathrm{~S}$ and/or $\mathrm{CO}_{2}$. They are also lightweight, have high strength-to-weight ratio, and thus decrease the existing tensions in the string and reduce well construction costs.
\end{abstract}

\section{Description of the oilfield for application test}

For Bayandyskoye oilfield, belonging to "LUKOILKomi" LLC, within the framework of pilot works the 1953T1 aluminum alloy casing was designed, manufactured and successfully applied as a production sting.

Operating conditions:

- TMD 4219 meters;

- bottom-hole temperature $90^{\circ} \mathrm{C}$;

- the open hole diameter $215,9 \mathrm{~mm}$;

_ intermediate $244.5 \mathrm{~mm}$ casing string run to $2707 \mathrm{~m}$;

- hydrogen sulfide presence in formation fluids was up to $18.5 \%$ vol. and carbon dioxide $-1.1 \%$ vol.

The upper section of the second intermediate string $(\mathrm{D}=244.5 \mathrm{~mm})$ utilized imported pipes of 90SS strength group, and the lower section was made of Sanicro 29 (110) stainless steel pipes.

All casing pipes came with highly sealed Tenaris Blue threaded connections. Casing equipment (stage cementing collars, packers, valves) was also made with similar high-strength corrosion-resistant steel grades.

\section{Selection of aluminum alloy and corrosion testing}

The casing material selection was based on the results of corrosion tests in compliance with NACE TM0177, ASTM G47, GOST 9.019, ASTM G31, at different pressure and temperature of $88^{\circ} \mathrm{C}[1-5]$. Considering rated strength, corrosion resistance and based on results of stress-strain state analysis of casing string, a highstrength aluminum alloy $1953 \mathrm{~T} 1$ was chosen as a material for aluminium alloy casing. This material underwent complex testing in corrosion aggressive environment similar to well conditions [6].

Taking into account the different stages of the well construction process, corrosion tests were carried out in four environments:

- a mixture of oil, formation fluid and gas components (hydrogen sulfide and carbon dioxide), corresponds to the corrosive properties of the produced oil;

- the same, but without the oil component, corresponds to the formation fluid at the well completion stage.

- $\quad$ solution based on $\mathrm{HCl}$, imitating the acid treatment of the bottomhole zone.

- alkaline environment that simulates the conditions of cementing wells.

Tests in these environments include, above all, the standard types of corrosion tests:

- general corrosion;

- contact corrosion;

- corrosion cracking;

- special tests of samples that simulate the conditions of acid treatment and well cementing;

- autoclave tests.

\subsection{Tests in reservoir gas-saturated fluid - environments 1 and 2}

The mineral component of the test fluid was a water with a total mineralization level of $\sim 10 \%$, including $\sim 3 \%$ chloride.

Gas saturation was carried out with a mixture of gases: $13 \% \mathrm{H}_{2} \mathrm{~S}+1 \% \mathrm{CO}_{2}+$ the rest $\mathrm{N}_{2}$ supplied by contractors in one bottle at $\sim 100 \mathrm{~atm}$.

Autoclave tests were carried out for 30 days at a temperature of $88^{\circ} \mathrm{C}$ and pressures of $50 \mathrm{~atm}$ and 150 atm.

The 12 samples of aluminum alloy $1953 \mathrm{~T} 1$ were placed into each autoclave (Fig. 1). 


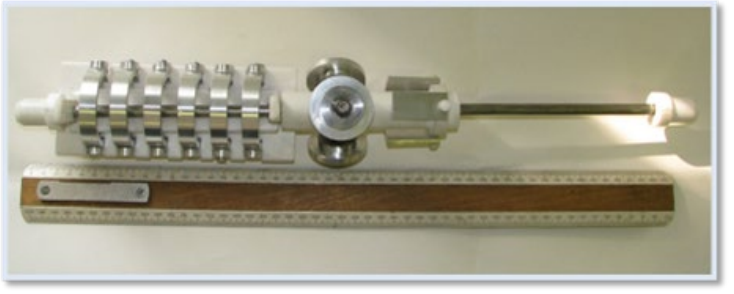

Fig. 1 General view of the samples before testing

After testing the surface of the samples for general corrosion was covered with small ulcers along the direction of polishing the samples. Visual examination of samples for contact corrosion revealed slight corrosion damage to aluminum alloy. Samples for corrosion cracking showed no susceptibility to corrosion cracking. Samples at all three levels of load did not break, no cracks were found in the working area of the samples (Fig. 2).

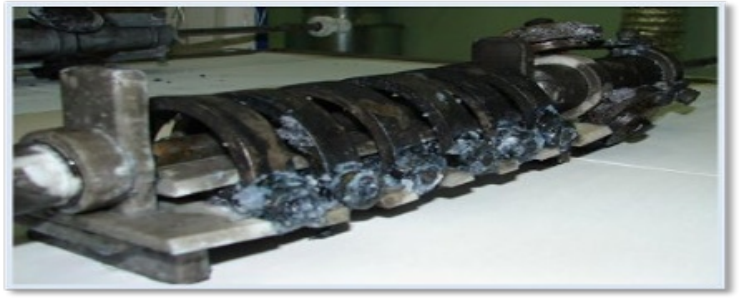

Fig.2 General view of the samples after autoclave tests at $\mathrm{P}=$ $150 \mathrm{~atm}$

\subsection{Tests in environment 3 - simulating acid treatment of wells.}

In solutions of hydrochloric acid at concentrations from 5 to $20 \%$ and exposure from 5 to 120 minutes, intense gas formation was observed.

\subsection{Test in environment 4 - simulating the conditions of cementing wells}

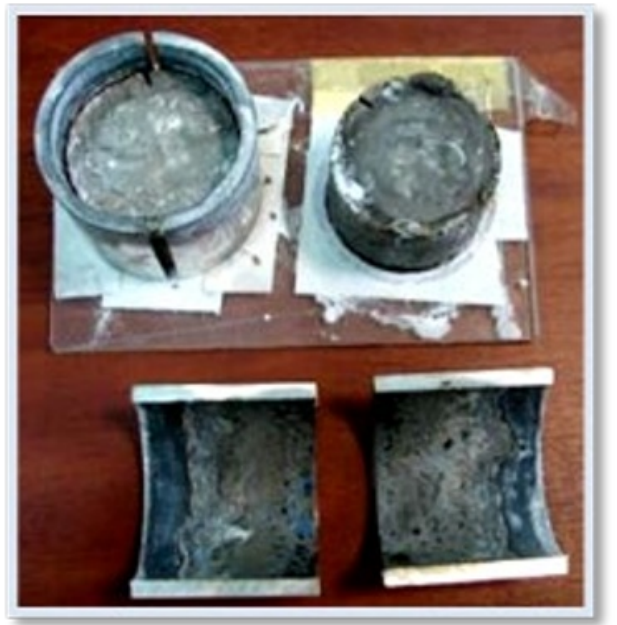

Fig.3 Samples after testing the interaction with cement slurry

Since after 10 days of testing, the nature of the inner surface of the pipe has not changed at all, it can be assumed that the cement slurry used in combination with the action of produced water does not affect the corrosion properties of $1953 \mathrm{~T} 1$ alloy.

\subsection{Acid treatment challenge}

Additional research has been fulfilled to demonstrate that sulfamic acid $\left(\mathrm{NH}_{2} \mathrm{SO}_{2} \mathrm{OH}\right)$, known as a noncorrosive solution for aluminum alloy, is effective in treatment of carbonate formations, thus making it a good substitute for $\mathrm{HCl}$ acid.

There was a necessity to check whether treatment with $15 \%$ sulfamic acid instead of $14 \%$ hydrogen chloride, which had been in use at the field, would result in increase of rock permeability. In order to achieve this, the Core and Formation Fluid Research Center of "PechorNIPIneft" LLC (Arkhangelsk) did some laboratory tests of acid solutions effects on productive formations of Bayandyskoe field.

For this test, several prepared core samples were taken from the productive Zadonsky horizon of Upper Devon deposits (4087-4185 m depth) from the earlier drilled exploratory wells. Lithologically, the samples were porous and cavernous limestone, microbial-detrital with secondary clotted, crumby and clastic structure (Fig. 4, 5).

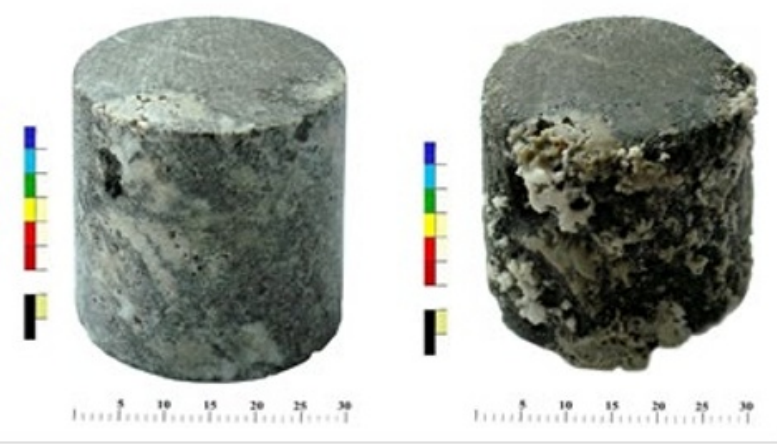

Fig. 4 Core sample before and after treatment with hydrogen chloride

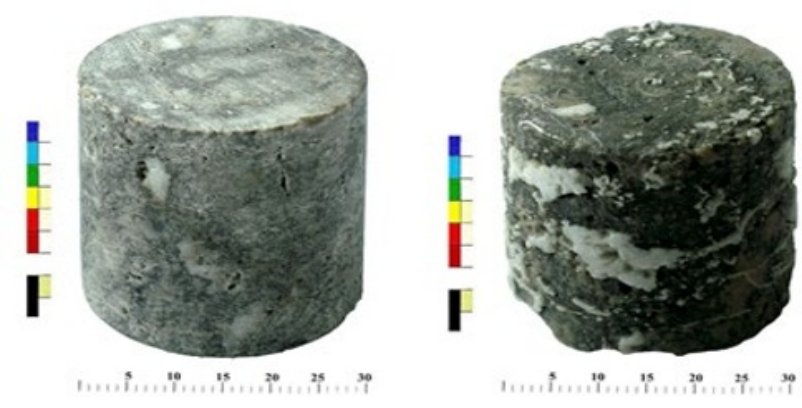

Fig. 5 Core sample before (a) and after treatment with sulfamic acid

The preliminary research included an express analysis of efficiency of sulfamic acid: dry weighed samples were immersed in $15 \%$ solution of sulfamic acid and in $14 \%$ solution of hydrogen chloride, after which a comparison was made of weight loss and solution $\mathrm{pH}$ change over time. The obtained data were used to assess rock dilution rate and change of this parameter over time. 
As a result of sulfamic acid treatment of samples with gas permeability over $2 \times 10^{-3}{\mu \mathrm{m}^{2}}^{2}$ have a substantial growth of permeability factor to $490 \times 10^{-3}-$ $840 \times 10^{-3} \mu \mathrm{m}^{2}$. Rock dilution rate with sulfamic acid is $2-2.5$ times slower than is the case with hydrogen chloride, yet the period of intensive dilution is longer with sulfamic acid (12-20 minutes for hydrogen chloride, 30-40 minutes for sulfamic acid).

Research has shown efficiency of employing sulfamic acid to treat rock in productive section of Bayandyskoe field.

\section{Strength tests}

For aluminum casing pipes with outside diameter of $177.8 \mathrm{~mm}$ the $14 \mathrm{~mm}$ wall thickness and OTTG premium thread was selected, based on FEA results. The design fully corresponds to the conditions of casing string run and operations. Full-scale samples of pipes have passed a series of tests on the test facilities of Krylov State Scientific Center in St. Petersburg, confirming the design characteristics.

They included:

- $\quad$ Test at $40 \mathrm{MPa}$ internal pressure;

- Test at combined application of $1.5 \times$ operating tensile load of $1800 \mathrm{kN}$ with simultaneous internal pressure of $40 \mathrm{MPa}$;

- Tensile strength test for ultimate tensile load until breaking

- Tightness test under ultimate internal pressure until burst (Fig.6);

- Pipe body collapse test under ultimate external pressure (Fig.7);

- Threaded connection collapse test under ultimate external pressure.

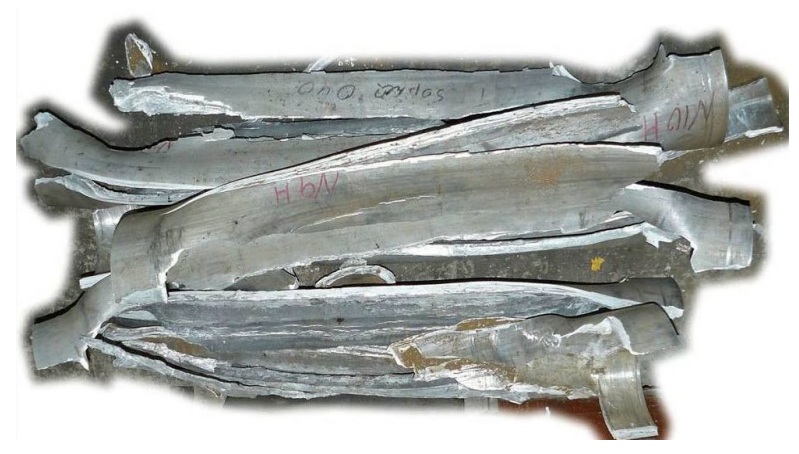

Fig.6 specimen of LOT178x14 pipe after internal pressure test

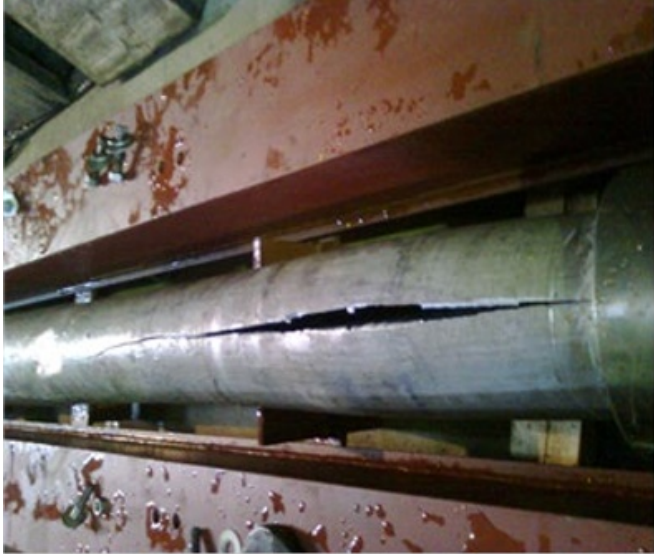

Fig.7 Specimens of LOT178x14 pipe after external pressure test

The bench trials of pipe body and threaded connection of full-size specimens of LOT178x14 pipes made of 1953T1 alloy showed the following:

Strength and tightness of threaded connections were confirmed for an internal pressure equal to $1.5 \times$ operational pressure, and combined effect of $40 \mathrm{MPa}$ internal pressure and $1800 \mathrm{kN}$ tensile load (1.5× operational load);

- It was confirmed that under ultimate internal pressure the tightness and strength of connection survived until the pipe body failure;

- $\quad$ Threaded connection did not reduce collapsing external pressure of the pipe.

The results of tests were summarized in Table 1.

Table 1. Results of full-size specimens of LOT 178x14 tests

\begin{tabular}{|c|c|c|c|c|}
\hline$\# \begin{array}{l}\text { Specim } \\
\text { en type }\end{array}$ & Test type & \begin{tabular}{|l} 
Rated \\
fault \\
values
\end{tabular} & Test results & $\begin{array}{l}\text { Com } \\
\text { ments }\end{array}$ \\
\hline $1 \begin{array}{l}\text { OTTG- } \\
178 \\
\text { connec } \\
\text { tion }\end{array}$ & $\begin{array}{l}\text { Internal } \\
\text { pressure } \\
\text { with tension } \\
\text { to breaking }\end{array}$ & $3460 \mathrm{kN}$ & $\begin{array}{c}\text { Tight } @ \mathrm{P}=40 \\
\mathrm{MPa}, \mathrm{F}=1800 \\
\mathrm{kN} \\
\text { Breaking at } \\
\text { connection } \\
\mathrm{F}_{\mathrm{br}}=3540 \mathrm{kN}\end{array}$ & $\begin{array}{l}\text { one } \\
\text { speci } \\
\text { men }\end{array}$ \\
\hline $2 \begin{array}{l}\text { OTTG- } \\
178 \\
\text { connec } \\
\text { tion }\end{array}$ & $\begin{array}{l}\text { Tightness } \\
\text { test }\end{array}$ & - & $\begin{array}{c}\text { Tight @ } @ \mathrm{P}=42 \\
\mathrm{MPa}\end{array}$ & $\begin{array}{l}\text { one } \\
\text { speci } \\
\text { men }\end{array}$ \\
\hline $\begin{array}{l}\text { OTTG- } \\
178 \\
\text { connec } \\
\text { tion }\end{array}$ & $\begin{array}{l}\text { External } \\
\text { pressure to } \\
\text { collapse }\end{array}$ & $42 \mathrm{MPa}$ & $\begin{array}{c}\text { Collapse @ } \\
\mathrm{P}_{\text {coll }}=78 \mathrm{MPa}\end{array}$ & $\begin{array}{l}\text { one } \\
\text { speci } \\
\text { men }\end{array}$ \\
\hline $4 \begin{array}{l}\text { Pipe } \\
\text { body }\end{array}$ & $\begin{array}{l}\text { External } \\
\text { pressure to } \\
\text { collapse }\end{array}$ & $42 \mathrm{MPa}$ & $\begin{array}{c}\text { Collapse @ } \\
\mathrm{P}_{\text {coll }}=74 \mathrm{MPa} \\
\text { and } \mathrm{P}_{\text {coll }}=68 \\
\mathrm{MPa}\end{array}$ & $\begin{array}{l}\text { two } \\
\text { speci } \\
\text { mens }\end{array}$ \\
\hline $5 \begin{array}{l}\text { Conne } \\
\text { ction } \\
\text { and } \\
\text { pipe } \\
\text { body }\end{array}$ & $\begin{array}{l}\text { Internal } \\
\text { pressure to } \\
\text { burst }\end{array}$ & $66 \mathrm{MPa}$ & $\begin{array}{c}\text { Pipe body } \\
\text { burst } @ \\
P_{b r}=90 \mathrm{MPa}\end{array}$ & $\begin{array}{l}\text { one } \\
\text { speci } \\
\text { men }\end{array}$ \\
\hline
\end{tabular}




\section{Field trials}

All pipes have been tested for internal pressure before delivery to the rig site. Compared with 4219 meters 7" steel casing, weight in air of aluminum casing decreased from $1316 \mathrm{KN}$ to $608 \mathrm{KN}$.

The casing string was successfully run in a hole to target depth, cemented and perforated. After sulfamic acid stimulation, the well worked for about three years with the expected debits. The reason for stopping production was the watering of products. Currently, it is planned to install a cut-off bridge and the transition to production from the overlying interval.

\section{Conclusion}

The designed aluminum alloy casing fully met requirements for strength and corrosion resistance, which are set for the pipes to be used in aggressive environments with high content of $\mathrm{H}_{2} \mathrm{~S}$ and $\mathrm{CO}_{2}$.

\section{References}

1. GOST 632-80 "Casing pipes and couplings for them. Specification".

2. NACE TM 0177, "Standard Test Methods. Laboratory Testing of Metals for Resistance to Sulfide Stress Cracking and Stress Corrosion Cracking in H2S Environments".

3. ASTM G47 "Standard Test Method for Determining Susceptibility to Stress-Corrosion Cracking of 2XXX and 7XXX Aluminum Alloy Products"

4. GOST 9.019 "Unified system of corrosion and ageing protection. Aluminum and magnesium alloys. Accelerated test methods for corrosion cracking.

5. ASTM G31 "Standard Practice for Laboratory Immersion Corrosion Testing of Metals".

6. Basovich V.S, Gelfgat M.Ya, Basovich D.V, et. al. "Aluminium Alloys for Casing and Tubing", paper IPTC14888 presented at the International Petroleum Technology Conference, Bangkok, Thailand, 15-17 November 2011 